\title{
Use coal or invest in renewables: a real options analysis of energy investments in the Philippines
}

\author{
Casper Boongaling Agaton * (i)
}

\begin{abstract}
This paper aims to analyze the comparative attractiveness of either investing in various renewable energy sources or continue using coal for electricity generation in the Philippines. Using real options approach, this research evaluates the investment value and trigger prices of coal for switching technologies with some scenarios in coal price uncertainty and social discount rate. The results find that investing in renewable energy is a better option than continue using coal for electricity generation. Among renewable energy sources, geothermal is the most attractive to invest to, followed by wind, hydroelectric, and solar photovoltaic.
\end{abstract}

Keywords: Renewable energy, Investment under uncertainty, Real options, Dynamic optimization

\section{Background}

To reduce the risk of climate change and support a sustainable future, governments and businesses around the world are investing in renewable sources of energy such as wind, hydropower, solar, biomass, and geothermal. In the recent years, the costs of renewable energy are declining fast and becoming cost-competitive against fossil fuel-based alternatives in many countries. These boost the growth of renewable energy investments setting a record high in 2015 of US\$249 billion, with a shift in geographic concentration in the developing countries around the Asia-Pacific region (Bloomberg 2016). In the Philippines, renewable energy accounts to $24 \%$ of the total electricity generation in 2016 (Department of Energy (DOE) 2017). The country is aiming to increase this value to $60 \%$ by 2030 by developing localized renewable energy resources (DOE 2012). The country's geographic location in the Pacific makes it a good potential for renewable energy generation with $76.6 \mathrm{GW}$ wind, $10 \mathrm{GW}$ hydropower, $5 \mathrm{kWh} / \mathrm{m}^{2} /$ day solar, $500 \mathrm{MW}$ biomass, $170 \mathrm{GW}$ ocean, and $4 \mathrm{GW}$ geothermal (International Renewable Energy Agency (IRENA) 2017). Despite

${ }^{*}$ Correspondence: Casper.Agaton@rub.de

Institute of Development Research and Development Policy, Ruhr

University of Bochum, Universitaetsstr. 105, 44789 Bochum, Germany the renewable energy potential in the country, investments in these sources are challenged by high startup and technology cost, competitive prices of fossil fuels, and non-viable markets.

This paper proposes a general energy investment framework that can be applied to developing countries. The main objective is to analyze the comparative attractiveness of either continue using coal or switching to renewable energy sources for electricity generation using the case of the Philippines. Applying the real options approach (ROA) under uncertainty, this research evaluates the value of investment and identifies the optimal timing of investment in various types of renewables. A sensitivity analysis is conducted to investigate the dynamics of investment value and optimal timing of investment under the changes in discount rates and volatility of coal prices.

The application of ROA approach is becoming more popular in valuating energy projects as it covers essential characteristics of investment. First characteristic is the irreversibility in which the investment cost cannot be recovered once it is installed (Pindyck 1993). Second, ROA addresses the uncertainties in investment including interest rates, technological progress, energy policy, and market prices (Kumbaroğlu et al. 2008). 
Third is the flexibility in which investors can invest immediately or delay the decision into a lesser risk and more profitable period of investment (Yang et al. 2008). Recent applications of ROA, particularly in renewable energy investments, include Eissa and Tian (2017) who investigated the real options framework for solar power project considering the renewable certificate price and cost of delay between establishing and operating the solar power plant; Kim et al. (2017) who assessed the renewable energy investment in developing countries with a case study involving a hydropower project in Indonesia; Kitzing et al. (2017) who evaluated offshore wind energy investments in Baltic Sea under uncertainties in feed-in tariffs (FiT), feed-in premiums, and tradable green certificates; Loncar et al. (2017) who used a compound real options valuation method to examine a potential onshore wind farm project in Serbia; and Zhang et al. (2017) on estimating the optimal subsidy for renewable energy power generation project in China by using stochastic process to describe the market price of electricity, $\mathrm{CO}_{2}$ price, and investment cost. Further, Barrera et al. (2016) analyzed the impact of public research and development (R\&D) financing on renewable energy projects, specifically on concentrated solar power; Eryilmaz and Homans (2016) examined the investment decisions of US renewable energy producers considering the uncertainties in federal government's continuation of the production tax credit policy and the market prices for renewable electricity credits; Fleten et al. (2016) studied whether investors in renewable energy projects in Norway exert discretion about the timing of investment decisions when they face uncertainties in electricity price and subsidy; Ritzenhofen and Spinler (2016) assessed the impact of adjustments in FiT schemes on investment in renewable energy sources; Sisodia et al. (2016) evaluated the investment strategies in wind-generated energy projects in Portugal under the risk in regulatory changes in Spain; and Wesseh et al. (2016) evaluated whether the feed-in-tariffs outweigh the cost of wind energy projects in China. To the best of author's knowledge, there has not been any study analyzing investment decisions with various renewable energy options applying the ROA under uncertainty. This study contributes to these literatures by applying ROA, to analyze investment strategies of shifting technologies from coal to renewable energy sources (RES) including wind, solar PV, hydropower, and geothermal. Applying the case of the Philippines, this further identifies scenarios where investment in renewables becomes better alternative to coal for electricity generation.

\section{Methods}

This study uses the real options approach to identify the trigger prices of coal for switching technologies from coal to renewable energy sources. A series of processes are employed including the evaluation of the net present values (NPV) of investment in renewables and coal, application of stochastic process and Monte Carlo simulations to estimate the expected net present value of using coal, and dynamic optimization to calculate the real option values of either investing in renewables of continue using coal. The ROA framework in this study takes the point of view of an investor who decides to invest in RES within a specific period of investment. Within this period, the investor has the option to delay the investment and select the optimal timing to maximize the project value under uncertainty (Zhang et al. 2017; Hach and Spinler 2016; Pringles et al. 2015).

\section{Net present value of investment in renewable energy}

Adopting the social revenue function described by Detert and Kotani (2013), Twidell and Weir (2015), and Savino et al. (2017), the NPV for shifting to renewable energy sources is described by

$$
\begin{aligned}
& \mathrm{NPV}_{\mathrm{R}}=\sum_{t=0}^{T_{\mathrm{R}}} \mathrm{PV}_{\mathrm{R}, t}-I_{\mathrm{R}}=\sum_{t=0}^{T_{\mathrm{R}}} \rho^{t} \pi_{\mathrm{R}, t}-I_{\mathrm{R}} \\
& \pi_{\mathrm{R}, t}=P_{\mathrm{E}} Q_{\mathrm{E}}-C_{\mathrm{R}}
\end{aligned}
$$

where $\pi_{R, t}$ is the annual revenue for after making the technological switch; $R$ is the renewable source including wind, solar, hydro, and geothermal; $I_{R}$ is the overnight cost for renewables; $P_{\mathrm{E}}$ is the domestic electricity price in the Philippines; $Q_{\mathrm{E}}$ is the annual electricity generated from renewables; $C_{R}$ is the annual O\&M cost; $\rho$ is the discount factor equal to $1 / 1+r ; r$ is the social discount rate; $t$ is the period of investment; and $T_{\mathrm{R}}$ is the lifetime of renewable energy generation.

\section{Net present value of using coal}

The social revenue for continue using coal for electricity generation is described by

$$
\begin{aligned}
& \mathrm{NPV}_{\mathrm{C}}=\sum_{t=0}^{T_{\mathrm{C}}} \mathrm{PV}_{\mathrm{C}, t}=\sum_{t=0}^{T_{\mathrm{C}}} \rho^{t} \pi_{\mathrm{C}, t} \\
& \pi_{\mathrm{c}, t}=P_{\mathrm{E}} Q_{\mathrm{E}}-P_{\mathrm{c}, t} Q_{\mathrm{c}}-C_{\mathrm{c}}
\end{aligned}
$$

where $\pi_{C, t}$ is the annual revenue for continuing the use of coal; $C_{\mathrm{c}}$ is the annual O\&M cost for coal; $Q_{\mathrm{c}}$ is the amount of coal needed to generate $Q_{\mathrm{E}}, T_{\mathrm{C}}$ is the number of years 
the coal can be used after the terminal period; and $P_{\mathrm{c}, t}$ is the stochastic price of coal which is described in the next subsection.

\section{Stochastic process and Monte Carlo simulation}

In line with previous literatures, this study assumes that price of coal is stochastic that changes randomly over time and follows geometric Brownian motion (GBM) with a drift (Tietjen et al. 2016; Wang and Du 2016; Xian et al. 2015). Dixit and Pindyck (1994) presents the stochastic price process as

$$
\frac{\mathrm{d} P}{P}=\alpha \mathrm{d} t+\sigma \mathrm{d} z
$$

where $\alpha$ and $\sigma$ are parameters of drift and variance representing mean and volatility of the price process, $\mathrm{d} t$ is the infinitesimal time increment, and $\mathrm{d} z$ is the increment of the Wiener process equal to $\varepsilon_{t} \sqrt{\mathrm{d} t}$ such that $\varepsilon_{t} \sim N(0,1)$. Adopting Insley (2002), $\alpha$ and $\sigma$ can be approximated using the ADF unit root test for the time series of coal prices (see Additional File 1: Table S2 for ADF unit root test result). These parameters are then employed in generating stochastic prices of coal using the equation

$$
P_{\mathrm{C}, t}=P_{\mathrm{C}, t-1}+\alpha P_{\mathrm{C}, t-1}+\sigma P_{\mathrm{C}, t-1} \varepsilon_{t-1}
$$

where $P_{\mathrm{C}, t}$ and $P_{\mathrm{C}, t-1}$ are the stochastic prices of coal at periods $t$ and $t-1$; and $\varepsilon_{t}$ is standard normally distributed such that $\varepsilon_{t} \sim N(0,1)$.

The expected net present value of using coal is calculated using Monte Carlo simulation as described by the equation

$$
\mathbb{E}\left\{\mathrm{NPV}_{\mathrm{C}, j} \mid P_{\mathrm{C}, 0}\right\} \approx \frac{1}{J} \sum_{j=1}^{J} \mathrm{NPV}_{\mathrm{C}, j} \approx \mathbb{E}\left\{\mathrm{NPV}_{\mathrm{C}} \mid P_{\mathrm{C}, \mathrm{C}}(\}\right)
$$

In this process, the $\mathrm{NPV}_{\mathrm{C}}$ is calculated repeatedly in an approximately large number of $J$ times considering the stochastic prices of coal. Computed $\mathrm{NPV}_{\mathrm{C}}$ are then averaged to estimate the expected net present value of using coal.

\section{Dynamic optimization and optimal trigger prices}

The real options model in this study is described by an investor who is given a period to decide to switch to renewable energy sources. After such period, there is no other choice but to continue using coal until the end of its lifetime. The decision-making process is done annually by maximizing the net present values of each option (coal or renewable). Adopting the work of Detert and Kotani (2013), option value at each period of investment is calculated using dynamic optimization as described by

$$
\begin{aligned}
& \max _{0 \leq \tau<T+1} \mathbb{E}\left\{\left[\sum_{0 \leq t<\tau} \rho^{t} \pi_{\mathrm{C}, t}+\rho^{T} \mathrm{NPV}_{\mathrm{C}, t}\left(1-\mathbb{I}_{\{\tau \leq T\}}\right)\right] \mid P_{\mathrm{C}, 0}\right\} \\
& +\left\{\mathrm{NPV}_{\mathrm{R}}\right\}\left(\mathbb{I}_{\{\tau \leq T\}}\right)
\end{aligned}
$$

$V_{t}\left(P_{\mathrm{C}, t}\right)=\max \left\{\mathrm{NPV}_{\mathrm{R}, \pi_{\mathrm{C}, t}}+\rho \mathbb{E}\left(V_{t+1}\left(P_{\mathrm{C}, t+1}\right) \mid P_{\mathrm{C}, t}\right)\right\}$

where $V_{t}\left(P_{\mathrm{C}, t}\right)$ is the option value at each price of coal $P_{\mathrm{C}, t}, T$ is the length of time where an investor has an option to switch to renewable energy; $\tau$ is the period where the switching is made; and $\mathbb{I}_{\{\tau \leq T\}}$ is an indicator function equal to 1 with $\tau \leq T$ otherwise 0 . In the given equation, the investor's problem is to find the optimal timing $\tau$ that maximizes the expected NPV of social revenues at each price of coal for every investment period. Estimated option values are plotted in graphs to identify the trigger prices of coal for switching technologies as represented by

$$
\widehat{P}_{\mathrm{C}}=\inf \left\{P_{\mathrm{C}, t} \mid V_{0}\left(P_{\mathrm{C}, t}\right)=V_{T_{\mathrm{R}}}\left(P_{\mathrm{C}, t}\right)\right\}
$$

where $\widehat{P}_{\mathrm{C}}$ is the trigger price or the minimum coal price $P_{C, t}$, while $V_{0}\left(P_{C, 0}\right)$ and $V_{T_{R}}\left(P_{C, 0}\right)$ are the maximized values of the investment at time $t=0$ and $t=T_{\mathrm{R}}$ (Dixit and Pindyck 1994; Davis and Cairns 2012).

\section{Data and scenarios}

To estimate the parameters for the optimization problem, the data are gathered from Philippine's Department of Energy (DOE). A standard quantity of electricity generation $Q_{\mathrm{E}}$ is set to $2165 \mathrm{GWh}$ such that all RES produce the same average annual output. This amount proposes $5 \%$ of the energy generation from coal to be replaced by renewable sources. The investment costs and other costs associated with the generation of electricity from various sources are then estimated. This study assumes that RES can generate electricity at an annual average of $Q_{E}$ all throughout its lifetime; there are no technological innovations that affect energy efficiency and overnight costs of renewables; no inflation; and prices of coal are stochastic and independent of the demand for renewable energy. All parameters used in this study are described in Additional file 1: Table S1.

To describe several investment environments in the Philippines, this study analyses the sensitivity of optimal investment decisions with respect to uncertainty in coal prices and discount rates. Higher uncertainty describes a situation with high volatility in coal prices. Meanwhile, lower uncertainty indicates a more deterministic trend in coal prices. Several discount rates are also employed from the present $10 \%$, to $12.5,7.5$, and $5 \%$. 


\section{Results}

The dynamic optimization of the real options model in this study yields two main results: option values and optimal trigger price. The option values at every period of investment are obtained by maximizing the value of using coal or shifting to renewables subject to stochastic prices of coal. From the options values, the trigger price is determined as the minimum price of coal that maximizes the option values between the initial period and the terminal period of investment. At this price of coal, switching to renewables is optimal.

The result of the dynamic optimization is shown in Fig. 1. The first point of interest is the line at the bottom of each option values curve. These lines represent the net present values of each renewable energy sources as summarized in Table 1 . The positive net present values indicate positive returns for all types of investment. Among the renewable energy sources, geothermal shows to be the most profitable followed by wind, hydropower, and lastly, solar PV. This is in line with the previous studies

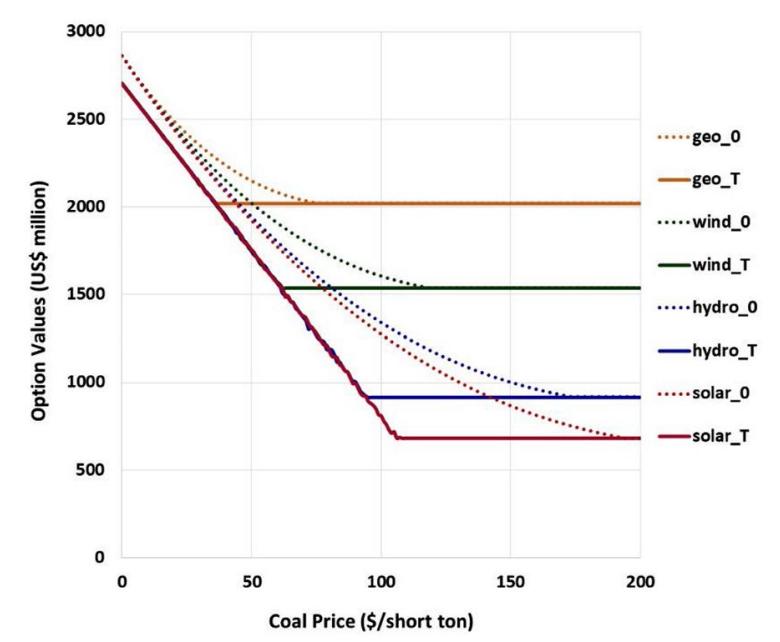

Fig. 1 Option values of various renewable energy sources. Note geo_0, geo_T, wind_0, wind_T, hydro_0, hydro_T, solar_0, and solar_T are option values for investment in geothermal, wind, hydropower, and solar PV at the initial (0) and terminal (T) period of investment (see Additional file 1: Table \$3 for the simulation result)

Table 1 Net present value of various renewable energy investments

\begin{tabular}{ll}
\hline & Net present value \\
\hline Geothermal & US\$2020M \\
Wind & US\$ 1538M \\
Hydroelectric & US\$917M \\
Solar PV & US\$681M \\
\hline
\end{tabular}

showing geothermal to be the cheapest form of energy and most attractive renewable energy investment among all other sources available in the country (Stich and Hamacher 2016; DOE 2014; Utama et al. 2012). Meanwhile, the data from DOE further show that majority of renewable sources in the country is coming from both geothermal (12\% of total generation) and hydropower ( $9 \%$ of total generation). Currently, the country is the world's second largest producer of geothermal energy second to the USA (Sovacool 2010). The use of new renewable energy sources including solar and wind energy has also dramatically increased in the recent years because of the favorable renewable energy policy framework and investments from the private sector (IRENA 2017). However, it should be noted that NPV is not the sole determinant of investments in a real options approach as the option values and optimal timing that maximize the value of investment opportunity must also be accounted for (Dixit and Pindyck 1994).

The next point of interest is the option values of various RES as shown in Fig. 1. Each point on the curves describes the maximized value of investment for every price of coal. It can be observed that the option values are greater or equal than the NPV. This is because the real option value equals the net present value of an investment plus the value of management flexibility (Santos et al. 2014; Yeo and Qui 2003; Trigeorgis 1996). This highlights the advantage of using ROA over traditional project valuation methods as it combines uncertainty and risk with flexibility while considering the volatility in investment as a potential positive factor which gives additional value to the project (Brach 2003). Among the option value curves in Fig. 1, investment in geothermal energy showed the highest real option values followed by wind, hydroelectric, and solar PV. This implies that among various RES options, geothermal seems to be the most attractive investment.

Another point of interest is the dynamics of option values. The downward slope of the curves indicates that option values decrease with prices of coal. The point where option value curve meets the straight line is the point of indifference. This point indicates the price of coal where an investor is indifferent between a decision to opt for coal or renewables. After such point, an investor has no better option but to switch technologies to renewables to avoid welfare loses. The vertical distance between the option curve at the terminal period (broken curve) and initial period (bold curve) represents the benefit of the option to wait which is equal to $\left(V_{\mathrm{T}}\left(P_{\mathrm{C}, \mathrm{t}}\right)-V_{0}\left(P_{\mathrm{C}, t}\right)\right.$. It can be observed that as coal price increases from zero, the value of option to wait increases, then decreases, and finally equals zero. This only confirms that the option value and value of option to wait are not necessarily 
proportional with changes in coal price under the conditions set in the real options model.

The last point of interest is the optimal trigger price of coal for shifting technologies and the dynamics of trigger prices over time as shown in Figs. 1 and 2. From Fig. 1, the optimal trigger price is represented by the intersection of the option values curves between the terminal and the initial period of investment. At this point, the value of waiting to invest becomes zero, which signifies the optimal decision to shift technologies to renewables. The trigger prices for various renewable energy sources are $\$ 74$ for geothermal, $\$ 116$ for wind, $\$ 173$ for hydropower, and $\$ 194$ for solar. This only conforms the NPV result in Table 1 which implies geothermal as the most attractive renewable energy option in terms of the profit from investment under uncertainty in coal prices. Figure 2 also follows this conclusion as geothermal yields the lowest trigger price curves at every period of investment.

\section{Sensitivity in discount rate and volatility of coal price}

This portion of analysis describes how optimal strategies adjust with varying certain investment parameters. Table 2 shows the trigger prices of coal increases at different discount rates. As discount rate increases, the net present value of investment decreases due to a decrease in net cash flow after discounting. Lower net present values result to a lower option values thereby decreasing the benefit of switching technologies to renewables. Thus, higher discount rate increases the trigger price implying a more optimal decision to wait or to delay investment in renewables. This suggests that the government must set a discount rate lower than the current $10-15 \%$ to attract investors to renewable energies and add benefit to power

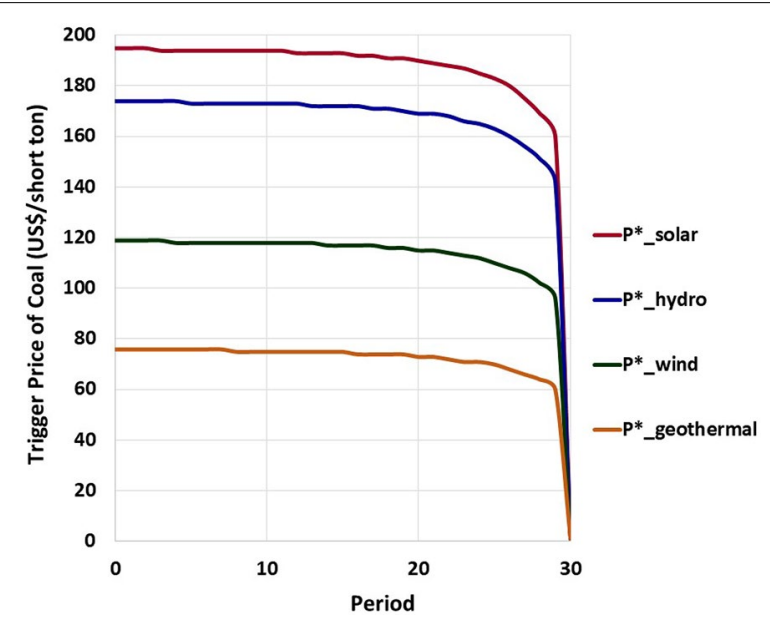

Fig. 2 Trigger coal price dynamics for various renewable energy sources at the baseline scenario. Note $P^{*}$ is the trigger price of coal at each period of investment (see Additional file 1:Table $\$ 4$ for simulation result)
Table 2 Optimal trigger prices of coal at various discount rates

\begin{tabular}{lllll}
\hline & \multicolumn{4}{l}{ Discount rate } \\
\cline { 2 - 5 } & $\mathbf{5 \%}$ & $\mathbf{7 . 5 \%}$ & Base (10\%) & $\mathbf{1 2 . 5 \%}$ \\
\hline Geothermal & $\$ 41$ & $\$ 58$ & $\$ 74$ & $\$ 97$ \\
Wind & $\$ 85$ & $\$ 92$ & $\$ 116$ & $\$ 152$ \\
Hydroelectric & $\$ 119$ & $\$ 136$ & $\$ 173$ & $\$ 218$ \\
Solar PV & $\$ 128$ & $\$ 152$ & $\$ 194$ & $\$ 224$ \\
\hline
\end{tabular}

producers to shift energy sources from coal to renewables. This result conforms with previous studies affirming that RES with higher proportion of capital investments are more expensive with high discount rate, while electricity generated from coal (and other fossil fuels) with significant proportion of operational and variable costs are far less susceptible to changes in discount rates due to lower capital costs (Copiello et al. 2017; Jeon et al. 2015; Pereira et al. 2013). Hence, lower social discount rates entail greater contributions of renewable technologies while higher social discount rates favor the use of fossil fuels (Gusano et al. 2016).

Table 3 shows the trigger prices at different volatilities in coal prices. The results show that at lower volatility of coal prices, option values increase, and the optimal trigger price of shifting to renewable decreases. This implies that with more deterministic prices of coal input, the better to invest earlier in renewables. On the other hand, when prices of coal input are more volatile in the market, it is better to wait and delay the investment to avoid losses from investment risks. This is because investors are risk averse, and they accept a riskier project only if they expect to receive a higher return to compensate it (Viallet and Hawawini 2015). Therefore, the higher the uncertainty over future cash flows, the lower the project's NPV and real option value, and lesser attractive to investors (Fagiani et al. 2013).

\section{Limitations and discussion}

To develop a ROA framework of energy investment decision, this study made several simplifying assumptions leading to various limitations in the analyses. First, the coal prices are assumed to be stochastic and follow GBM. With the positive drift of coal prices from the ADF unit root test, this assumes that the prices are increasing in the long run. With coal being an exhaustible resource, the current demand path and competition may accelerate the upward trend in prices with higher volatility and uncertainty. On the other hand, this paper acknowledges that the rapid developments in renewable technologies may eventually reduce the demand for coal and its price. This trend in coal price and demand should be accounted for. 
Table 3 Optimal trigger prices of coal at various coal price uncertainties

\begin{tabular}{llll}
\hline & \multicolumn{2}{c}{ Coal price uncertainty } \\
\cline { 2 - 4 } & Low & Base & High \\
\hline Geothermal & $\$ 61$ & $\$ 74$ & $\$ 85$ \\
Wind & $\$ 95$ & $\$ 116$ & $\$ 133$ \\
Hydroelectric & $\$ 142$ & $\$ 173$ & $\$ 198$ \\
Solar PV & $\$ 159$ & $\$ 194$ & $\$ 222$ \\
\hline
\end{tabular}

Moreover, different models to describe stochastic prices of fossil fuels could also be used for further comparison of results using GBM.

The study applies ROA under uncertainty in fuel prices and social discount factor. This paper acknowledges other uncertainties that affect investment decisions particularly to renewable energy. These include inflation that affects estimates of future cash flow; changes in FiT rates and market price of electricity; FiT subsidies and other government incentives; technological innovation that could lower the investment cost for RES; and environmental policy by imposing externality tax and green energy certificates (Eissa and Tian 2017; Kitzing et al. 2017; Zhang et al. 2017; Byrnes et al. 2016; Eryilmaz and Homans 2016; Kamjoo et al. 2016; Arnold and Yildiz 2015). The proposed ROA could be extended by incorporating these uncertainties to make a better investment strategy and comparison among various energy sources.

This study focuses only on the financial side of renewable energy investment. In real project valuation and decision-making process, there are also several factors considered including economic impacts on employment, electricity prices, and local economy; environmental impacts on landscape, wildlife, noise level and quality of air; and socio-technical factors including user's energy demand, usage patterns, system sizing, and availability of renewable resources (Barros et al. 2017; Akinyele and Rayudu 2016; Akinyele et al. 2015; Emmanouilides and Sgouromalli 2013). Future studies could incorporate these factors to make the current ROA model more robust and valuable only to investors but to project evaluators and policy makers as well.

Although there are some limitations, the ROA framework proposed in this study could be a good benchmark for further analysis of investment decisions for cleaner and more sustainable sources of energy.

\section{Conclusion}

This study presented investment environments for switching coal-based electricity generation to renewable energy by incorporating the option to delay or to wait in making an investment decision. Using MATLAB programming, dynamic optimization processes were done to evaluate the option values of investments and the timing switching technologies. Sensitivity analyses were performed to identify how uncertainty in coal prices and discount rates affect the investment decision-making process. By applying the real options approach, this study characterized scenarios where renewable energy became more attractive option than continue using coal. Among the renewable sources, geothermal energy showed to be the most profitable option followed by wind, hydroelectric, and solar PV. More deterministic coal prices and lower discount rates decreased the trigger prices of coal suggesting an earlier shifting of technologies from coal to renewables. Furthermore, higher coal price uncertainty and higher discount rate indicated a more optimal decision to delay investment in renewable energy.

\section{Additional file}

Additional file 1: Table S1. The table summarizes all variables and estimated parameters used in the dynamic optimization. Table S2. ADF unit root test result for coal prices from 1984-2016. Table S3. geo 0: option values for geothermal at the initial period. geo_T: option values for geothermal at the terminal period. wind_0: option values for wind at the initial period. wind_T: option values for wind at the terminal period. hydro_0: option values for hydro at the initial period. hydro_T: option values for hydro at the terminal period. solar_0: option values for solar at the initial period. solar_T: option values for solar at the terminal period. Table S4. Trigger prices of coal for shifting technology from coal to various renewable energy sources at different periods of investment.

\section{Abbreviations}

DOE: Philippines' Department of Energy; ENPV: expected net present value; GBM: geometric Brownian motion; FiT: feed-in tariff; IRENA: International Renewable Energy Agency; NPV: net present value; O\&M: operations and maintenance; PV: photovoltaic; RES: renewable energy resources; ROA: real options approach.

\section{Authors' information}

CBA is Ph.D. candidate in International Development Studies at the Institute of Development Research and Development Policy of the Ruhr University of Bochum in Germany.

\section{Acknowledgements}

The author acknowledges the support of the German Research Foundation (DFG) Open Access Publication Funds of the Ruhr-Universität Bochum.

\section{Competing interests}

The authors declare that he has no competing interests associated with this publication and the research has been carried out for a purely academic purpose.

Availability of data and materials

The data and materials are available anytime from the author, as per request.

Ethics approval and consent to participate

The author declares that this study does not involve human subjects, human material, and human data. 


\section{Funding}

Not applicable.

\section{Publisher's Note}

Springer Nature remains neutral with regard to jurisdictional claims in published maps and institutional affiliations.

Received: 23 September 2017 Accepted: 16 January 2018 Published online: 25 January 2018

\section{References}

Akinyele, D. O., \& Rayudu, R. K. (2016). Strategy for developing energy systems for remote communities: Insights to best practices and sustainability. Sustainable Energy Technologies and Assessments, 16, 106-127. https://doi. org/10.1016/j.seta.2016.05.001.

Akinyele, D. O., Rayudu, R. K., \& Nair, N. K. C. (2015). Development of photovoltaic power plant for remote residential applications: The socio-technical and economic perspectives. Applied Energy, 155, 131-149. https://doi. org/10.1016/j.apenergy.2015.05.091.

Arnold, U., \& Yildiz, O. (2015). Economic risk analysis of decentralized renewable energy infrastructures-A Monte Carlo Simulation approach. Renewable Energy, 77, 227-239. https://doi.org/10.1016/j.renene.2014.11.059.

Barrera, G. M., Ramírez, C. Z., \& González, J. M. (2016). Application of real options valuation for analysing the impact of public R\&D financing on renewable energy projects: A company's perspective. Renewable and Sustainable Energy Reviews, 63, 292-301. https://doi.org/10.1016/j. rser.2016.05.073.

Barros, J. J. C., Coira, M. L., López, M. P. L. C., \& Gochi, A. D. C. (2017). Comparative analysis of direct employment generated by renewable and nonrenewable power plants. Energy, 139, 542-554. https://doi.org/10.1016/j. energy.2017.08.025.

Bloomberg New Energy Finance (BNEF). (2016). New energy outlook 2016: Powering a changing world. https://about.bnef.com/new-energy-outlook/. Accessed August 12, 2017.

Brach, M. A. (2003). Real options in practice. Hoboken: Wiley.

Byrnes, L., Brown, C., Wagner, L., \& Foster, J. (2016). Reviewing the viability of renewable energy in community electrification: The case of remote Western Australian communities. Renewable and Sustainable Energy Reviews, 59, 470-481. https://doi.org/10.1016/..rser.2015.12.273.

Copiello, S., Gabrielli, L., \& Bonifaci, P. (2017). Evaluation of energy retrofit in buildings under conditions of uncertainty: The prominence of the discount rate. Energy, 137, 104-117. https://doi.org/10.1016/j. energy.2017.06.159.

Davis, G. A., \& Cairns, R. D. (2012). Good timing. The economics of optimal stopping. Journal of Dynamics and Control, 36, 255-265. https://doi. org/10.1016/j.jedc.2011.09.008.

Department of Energy (DOE). (2012). Philippine energy plan 2012-2030. https://www.doe.gov.ph/sites/default/files/pdf/pep/2012-2030_pep.pdf. Accessed August 22, 2017.

Department of Energy (DOE). (2014). Geothermal: cheapest energy source. https://www.doe.gov.ph/energist/index.php/93-categorised/energy/ energy-resources/renewable-energy/geothermal-energy/4464-geothermal-cheapest-energy-source. Accessed December 10, 2017.

Department of Energy (DOE). (2017). 2016 Philippine power statistics. https:// www.doe.gov.ph/sites/default/files/pdf/energy_statistics/bgross_ power_generation_by_plant_2016.pdf. Accessed August 22, 2017.

Detert, N., \& Kotani, K. (2013). Real options approach to renewable energy investment in Mongolia. Energy Policy, 56, 136-150. https://doi. org/10.1016/j.enpol.2012.12.003.

Dixit, A. K., \& Pindyck, R. S. (1994). Investment under uncertainty. Princeton, NJ: Princeton University Press.

Eissa, M. A., \&Tian, B. (2017). Lobatto-Milstein numerical method in application of uncertainty investment of solar power projects. Energies, 10, 1-19. https://doi.org/10.3390/en10010043.

Emmanouilides, C. J., \& Sgouromalli, T. (2013). Renewable energy sources in crete: Economic valuation results from a stated choice experiment. Procedia Technology, 8, 406-415. https://doi.org/10.1016/j.protcy.2013.11.053.
Eryilmaz, D., \& Homans, F. R. (2016). How does uncertainty in renewable energy policy affect decisions to invest in wind energy? Electricity Journal, 29, 64-71. https://doi.org/10.1016/j.tej.2015.12.002.

Fagiani, R., Barquin, J., \& Hakvoort, R. (2013). Risk-based assessment of the cost-efficiency and the effectivity of renewable energy support schemes: Certificate markets versus feed-in tariffs. Energy Policy, 55, 648-661. https://doi.org/10.1016/j.enpol.2012.12.066.

Fleten, S. E., Linnerud, K., Molnár, P., \& Nygaard, M. T. (2016). Green electricity investment timing in practice: Real options or net present value? Energy, 116, 498-506. https://doi.org/10.1016/j.energy.2016.09.114.

Gusano, D. G., Espegren, K., Lind, A., \& Kirkengen, M. (2016). The role of the discount rates in energy systems optimisation models. Renewable and Sustainable Energy Reviews, 59, 56-72. https://doi.org/10.1016/j. rser.2015.12.359.

Hach, D., \& Spinler, S. (2016). Capacity payment impact on gas-fired generation investments under rising renewable feed-in-A real options analysis. Energy Economics, 53, 270-280. https://doi.org/10.1016/j. eneco.2014.04.022.

Insley, M. (2002). A real options approach to the valuation of a forestry investment. Journal of Environmental Economics and Management, 44(3), 471-492. https://doi.org/10.1006/jeem.2001.1209.

International Renewable Energy Agency (IRENA). (2017). Renewables readiness assessment: The Philippines. http://www.irena.org/DocumentDownloads/Publications/IRENA_RRA_Philippines_2017.pdf. Accessed August 22, 2017.

Jeon, D., Lee, J., \& Shin, J. (2015). Optimal subsidy estimation method using system dynamics and the real option model: Photovoltaic technology case. Applied Energy, 142, 33-43. https://doi.org/10.1016/j. apenergy.2014.12.067.

Kamjoo, A., Maheri, A., Dizqah, A. M., \& Putrus, G. A. (2016). Multi-objective design under uncertainties of hybrid renewable energy system using NSGA-II and chance constrained programming. International Journal of Electrical Power \& Energy Systems, 74, 187-194. https://doi.org/10.1016/j. ijepes.2015.07.007.

Kim, K., Park, H., \& Kim, H. (2017). Real options analysis for renewable energy investment decisions in developing countries. Renewable and Sustainable Energy Reviews, 75, 918-926. https://doi.org/10.1016/j. rser.2016.11.073.

Kitzing, L., Juul, N., Drud, M., \& Boomsma, T. K. (2017). A real options approach to analyse wind energy investments under different support schemes. Applied Energy, 188, 83-96. https://doi.org/10.1016/j. apenergy.2016.11.104.

Kumbaroğlu, G., Madlener, R., \& Demirel, M. (2008). A real options evaluation model for the diffusion prospects of new renewable power generation technologies. Energy Economics, 30(4), 1882-1908. https://doi. org/10.1016/j.eneco.2006.10.009.

Loncar, D., Milovanovic, I., Rakic, B., \& Radjenovic, T. (2017). Compound real options valuation of renewable energy projects: The case of a wind farm in Serbia. Renewable and Sustainable Energy Reviews, 75, 354-367. https:// doi.org/10.1016/.j.rser.2016.11.001.

Pereira, A. O. P., Jr., Cunha da Costa, R., do Vale Costa, C., de Moraes V, J., \& Lèbre La Rovere, E. (2013). Perspectives for the expansion of new renewable energy sources in Brazil. Renewable and Sustainable Energy Reviews, 23, 49-59. https://doi.org/10.1016/j.rser.2013.02.020.

Pindyck, R. S. (1993). Investments of uncertain cost. Journal of Financial Economics, 31(1), 53-76. https://doi.org/10.1016/0304-405X(93)90040-I.

Pringles, R., et al. (2015). Real option valuation of power transmission investments by stochastic simulation. Energy Economics, 47, 215-226. https:// doi.org/10.1016/j.eneco.2014.11.011.

Ritzenhofen, I., \& Spinler, S. (2016). Optimal design of feed-in-tariffs to stimulate renewable energy investments under regulatory uncertainty — A real options analysis. Energy Economics, 53, 76-89. https://doi.org/10.1016/j. eneco.2014.12.008.

Santos, L., Soares, I., Mendes, C., \& Ferreira, P. (2014). A real options approach to evaluating new nuclear power plants. Renewable Energy, 68, 588-594. https://doi.org/10.1016/j.renene.2014.01.038.

Savino, M. M., et al. (2017). A new model for environmental and economic evaluation of renewable energy systems: The case of wind turbines. Applied Energy, 189, 739-752. https://doi.org/10.1016/j. apenergy.2016.11.124. 
Sisodia, G. S., Soares, I., \& Ferreira, P. (2016). Modeling business risk: The effect of regulatory revision on renewable energy investment-The Iberian case. Renewable Energy, 95, 303-313. https://doi.org/10.1016/j. renene.2016.03.076.

Sovacool, B. K. (2010). A comparative analysis of renewable electricity support mechanisms for Southeast Asia. Energy, 35, 1779-1793. https://doi. org/10.1016/j.energy.2009.12.030.

Stich, J., \& Hamacher, T. (2016). The cost-effectiveness of power generation from geothermal potentials in Indonesia and the Philippines. IEEE Innovative Smart Grid Technologies_Asia, 54, 177-182. https://doi.org/10.1109/ isgt-asia.2016.7796382.

Tietjen, O., Pahle, M., \& Fuss, S. (2016). Investment risks in power generation: A comparison of fossil fuel and renewable energy dominated markets. Energy Economics, 58, 174-185. https://doi.org/10.1016/j. eneco.2016.07.005.

Trigeorgis, L. (1996). Real options: Managerial flexibility and strategy in resource allocation. Cambridge: MIT Press.

Twidell, J., \& Weir, T. (2015). Renewable energy resources. London: Routledge.

Utama, N. A., Ishihara, K. N., \& Tezuka, T. (2012). Power generation optimization in ASEAN by 2030. Energy and Power Engineering, 4, 226-232. https://doi. org/10.4236/epe.2012.44031.

Viallet, C., \& Hawawini, G. (2015). Finance for executives: Managing for value creation. Boston: Cengage Learning Emea.
Wang, X., \& Du, (2016). Study on carbon capture and storage (CCS) investment decision-making based on real options for China's coal-fired power plants. Journal of Cleaner Production, 112(5), 4123-4131. https://doi. org/10.1016/j.jclepro.2015.07.112.

Wesseh, Jr, Presley, K., \& Lin, B. (2016). A real options valuation of Chinese wind energy technologies for power generation: Do benefits from the feed-in tariffs outweigh costs? Journal of Cleaner Production, 112(2), 1591-1599. https://doi.org/10.1016/j.jclepro.2015.04.083.

Xian, H., Colson, G., Mei, B., \& Wetzstein, M. E. (2015). Co-firing coal with wood pellets for US electricity generation: A real options analysis. Energy Policy, 81, 106-116. https://doi.org/10.1016/j.enpol.2015.02.026

Yang, M., Blyth, W., Bradley, R., Bunn, D., Clarke, C., \& Wilson, T. (2008). Evaluating the power investment options with uncertainty in climate policy. Energy Economics, 30(4), 1933-1950. https://doi.org/10.1016/j. eneco.2007.06.004

Yeo, K. T., \& Qui, F. (2003). The value of management flexibility —A real option approach to investment evaluation. International Journal of Project Management, 21, 243-250. https://doi.org/10.1016/ S0263-7863(02)00025-X.

Zhang, M. M., Zhou, D. Q., Zhou, P., \& Chen, H. T. (2017). Optimal design of subsidy to stimulate renewable energy investments: The case of China. Renewable and Sustainable Energy Reviews, 71, 873-883. https://doi. org/10.1016/j.rser.2016.12.115.

\section{Submit your manuscript to a SpringerOpen ${ }^{\odot}$ journal and benefit from:}

- Convenient online submission

- Rigorous peer review

- Open access: articles freely available online

- High visibility within the field

- Retaining the copyright to your article

Submit your next manuscript at $\gg$ springeropen.com 